\title{
A CONFIGURAÇÃO DA VIA PÚBLICA INTERFERINDO NA APREENSÃO DA PRAÇA: O CASO DE CONJUNTOS HABITACIONAIS EM TERESINA
}

\author{
THE CONFIGURATION OF THE PUBLIC STREET INTERFERING IN THE USE OF THE PLAZA: THE CASE \\ OF HOUSING DEVELOPMENTS IN TERESINA
}

\section{LOPES, Wilza Gomes Reis}

Arquiteta, professora doutora do Departamento de Construção Civil e Arquitetura/Centro de Tecnologia da UFPI.

E-mail: izalopes@uol.com.br

\author{
ALVES, Marta Raquel da Silva \\ Acadêmica de arquitetura e urbanismo, Centro de Tecnologia/UFPI. \\ E-mail: martarachel@yahoo.com.br
}

\section{SOUSA, Giuliana de Brito}

Acadêmica de arquitetura e urbanismo, Centro de Tecnologia/UFPI.

E-mail: giulianaarq@yahoo.com.br

\section{RESUMO}

Comércio e espaços de lazer já estiveram juntos por muito tempo, na Idade Média o mercado assumia o papel que hoje cabe à praça o de espaço coletivo de lazer. Hoje o mercado adquire a função eminentemente de consumo, não se vivencia mais o ambiente e as pessoas. A busca incessante pelo lucro, ou mesmo pela sobrevivência, move nossa sociedade e cada local que pode potencialmente render dinheiro é explorado ao máximo. Casas localizadas próximas de ruas movimentadas transformam-se rapidamente em pontos comerciais, alterando a configuração de um espaço criado para moradia em ambiente de comércio. Mas essas vias não são povoadas apenas por estabelecimentos privados, elas apresentam também espaços públicos, que sofrem as conseqüências dessas alterações. $\bigcirc$ presente trabalho apresenta um estudo de três praças localizadas nos conjuntos habitacionais Itararé, Parque Piauí e Parque Promorar, na cidade de Teresina, Piauí, observando como as mudanças na função original das ruas do entorno, que foram projetadas, inicialmente, como ambiente residencial, têm modificado o desempenho dos espaços públicos.

Palavras-chave: Espaço público, comércio, apropriação.

\begin{abstract}
Commerce and spaces of leisure already had been together for much time, in the Average Age the market assumed the role that today fits to the square of collective space of leisure. Today the market acquires the consumption function eminently, more is not lived deeply the environment and the people. The incessant search for the profit, or same for the survival, moves our society and each place that can potentially relieve money is explored to the maximum. Located houses next to moving streets are changedded quickly into commercial points, modifying the configuration of a space created for housing in commerce environment. But these ways are not populated only by private establishments, them also present public spaces, that suffer the consequences of these alterations. The present work presents a study of three squares located in the habitacionais sets Itararé, Piauí Park and Promorar Park, in the city of Teresina, Piauí, observing as the changes in the original function of the streets of entorno, that they had been projected, initially, as surrounding residential, have modified the performance of the public spaces.
\end{abstract}

Key words: Open space, commerce, appropriation. 


\section{1 - Introdução}

\section{1 - Espaços públicos}

Os espaços públicos são lugares democráticos destinados a suprir a necessidade de lazer tão essencial ao homem. Agregando uma grande variedade de pessoas, que realizam ali as mais diferentes funções, esses espaços transpiram coletividade e integração. Segundo Farias (2000), os espaços públicos nos remetem à idéia de espaços coletivos, local onde os moradores das cidades travam suas relações de identidade e, a partir daí, relações entre cidade e cidadão, no sentido de que esses espaços devem ser democráticos, percebidos e vivenciados no cotidiano e não só percebidos sem poder ser alcançados. A praça como é conhecida hoje, representa um ambiente ajardinado, destinado ao lazer ativo ou passivo, como ainda à convivência, apresentações culturais e cívicas.

Mas as praças sofreram mudanças no decorrer dos anos, no período Medieval havia dois tipos de praças: a do mercado e a da igreja. Em cidades planejadas, onde o traçado seguia a forma reticular, a praça do mercado era a mais freqüente, e se localizava nos espaços vazios da retícula, sempre rodeada por ruas, como descreve Morris (1998, p. 109): "en las poblaciones planeadas cuyo trazado se basa en una estructura en retícula rectangular, la plaza del mercado es el tipo mas frecuente. En este caso su forma general es la de un hueco en la retícula, rodeado por calles en sus cuatro lados".

No período medieval as ruas eram os espaços públicos onde se realizavam atividades de convivência e lazer, correspondendo às extensões das casas, configurando-se como um lugar de todos. Na Idade Média existiam ainda, as praças maiores, que permitiam abrigar reuniões públicas. As praças deste período se caracterizavam pela diversidade, assim como define Segawa (1996), a vida na praça pública era permeada pelo universo do riso, do escárnio, da festa, numa dinâmica distinta da cultura religiosa ou aristocrática.

Naquela época o espaço localizado defronte à igreja, assim como a praça do mercado, possuía a função de lazer e o que existia em comum nestes ambientes era a ausência de vegetação. Segundo Segawa (1996) para a Igreja a contemplação e deleite da natureza estimulavam o pecado, desta forma, como ela impunha valores, pensamentos e idéias, espaços bucólicos espalhados pela cidade não eram usuais. De acordo com Marx (1980), nas cidades coloniais brasileiras, a praça surgiu diante de capelas ou igrejas, de conventos ou irmandades religiosas, como local de reunião de pessoas e para o exercício de vários tipos de atividades.

Durante o Renascimento as praças possuíam, ainda, a função pública, em especial nos períodos de festas, onde recebiam os mais variados tipos de pessoas. A função continuará a mesma da praça medieval, assim como o entorno, formado de prédios públicos, religiosos, residenciais e do mercado. O que acontecerá no Renascimento será uma variedade maior de tipologias.

As praças acompanharam as mudanças no contexto social e urbano, e a partir do Renascimento, o verde é incorporado ao repertório urbano, como uma volta ao paraíso esquecido. Inicialmente localizadas nas periferias, nos terrenos alagadiços drenados para receber novos usos, as praças serão bastante apropriadas pela aristocracia da época, para realização de atividades desportivas, passeios e contemplação.

A partir do desenvolvimento mercantil com o fortalecimento da burguesia e conseqüente surgimento de classe assalariada, mudanças profundas ocorreram na sociedade e na organização espacial. A Revolução Industrial dá início a um processo de separação social e espacial que perdura até hoje.

Atualmente, as praças mantiveram a função de entretenimento coletivo. Mas ganham novas formas de usos e desenhos, procurando abranger um leque maior de pessoas, de anseios tão 
diversos. Nos bairros populares, as praças são importantes opções de lazer, pois podem representar uma das poucas opções disponíveis de passatempo. Segundo Robba e Macedo (2002, p. 15): "[...] alterou-se significativamente o papel da praça na urbe; todavia , o caráter social que sempre a caracterizou, permaneceu e permanece como sua mais intrínseca qualidade."

\section{2 - A rua}

As ruas se destacam nas cidades coloniais brasileiras, segundo Marx (1980, p. 43): "A vida urbana tem nas ruas o caminho das largos, dos edifícios importantes, do campo e das outras cidades. Confia-Ihes por isso a feira a procissão, o pretexto de encontro."

A rua deveria ser entendida como um espaço público de convivência entre os moradores, lugar de se relacionar e criar laços de amizade. No entanto, cada vez mais a rua afasta-se desse contexto social, segundo Hertzberger (1996, p. 49) isso se dá devido:

- "O aumento do tráfego motorizado e a prioridade que recebe;

- a organização sem critérios da área de acessos às moradias, em particular às portas da frente, por causa de vias indiretas e impessoais de acesso, tais como, galerias, elevadores, passagens cobertas (os inevitáveis subprodutos de construções muito altas) que diminuem o contato com o nível da rua;

- quanto melhores as condições econômicas das pessoas, menos elas necessitam dos vizinhos, e tendem a fazer menos coisas juntas;

- densidades reduzidas de moradias [...] as ruas de hoje estão bem mais vazias do que as do passado, além disso, a melhoria na qualidade e do aumento das moradias significa que as pessoas passam mais tempo dentro de casa e menos na rua."

Para Macedo (1995), à medida que aumenta as densidades de população e de verticalização da cidade, em função da expansão das atividades urbanas, pouco a pouco a rua perde suas características de áreas de lazer, destinando seu espaço, principalmente, à circulação de acesso dos lotes, tanto para pedestres como para veículos, bem como, para ponto de parada desses últimos. As praças, parques e espaços livres dos lotes ficam encarregados de cobrir esta falta.

O que se observa é que espaços, inicialmente, criados para possibilitar a comunicação e convivência, quando se limita a servir apenas de circulação, perdem seu caráter social, ou seja, gera esvaziamento da área, propiciado pela falta de diversidade de atividades e agitação cotidiana. A função de fortalecer as relações sociais entre a comunidade do entorno se perde por entre os altos muros e calçadas estreitas, e o hábito de sentar-se à porta de casa é substituído, devido ao grande movimento de veículos nas ruas, ao medo da violência urbana, à melhoria das moradias e da própria condição de vida das pessoas.

Se durante o Renascimento a rua sofre transformações para se adequar à nova realidade sócio-cultural, como a substituição das vielas e ruas medievais por vias de comunicação largas e arejadas, o mesmo acontece na modernidade. $O$ modernismo racionaliza as cidades, a setoriza, e contribui para a segregação espacial e, em detrimento de toda a gama de grupos que até então habitavam as ruas, o automóvel é priorizado. A rua deixa de ser extensão de casa para se tornar local perigoso, excludente e marginal. E como afirma Santos (1988), a rua e a casa não podem ter significados estanques, pois há instantes de quebra do cotidiano em que a rua é tratada como se fosse casa ou que a casa é aberta e tratada como se fosse rua.

176 Mas os projetos urbanos continuam evoluindo em direção oposta ao sentido social, conduzidos em direção a caminhos, cada vez mais, excludentes e beneficiando uma classe específica e de anseios próprios, que nem sempre condizem com a grande maioria da população. As minorias requerem ruas largas para facilitar a circulação de veículos e passeios estreitos, já que são 
pouco utilizados. Os pedestres são relegados a segundo plano, e o mesmo aparelho que no Renascimento priorizava o passeio, circulação, comunicação e socialização de pessoas, passa a ser encarado como mero ambiente de trânsito de indivíduos para acesso aos lotes urbanos, e que renega suas características históricas de área de lazer.

Na visão de Tramontano e Santos (2001), as ruas, praças e parques, alvos de processos sucessivos de deterioração, vão deixando de ser palco da vida cotidiana e de serem espaços de estar e de convívio social para tornarem-se meros territórios de passagem rápida.

Os conjuntos habitacionais continuam adotando esse modelo setorizado, com casas padronizadas e ruas estritamente residenciais. Essa setorização é posta em xeque a partir do momento em que se iniciam as ocupações, e os moradores começam a intervir nesses espaços para torná-los habitáveis e criar uma identidade. As vias arteriais rapidamente são convertidas de residencial para comercial, para facilitar aos moradores dos conjuntos o acesso a mercadorias, sem que necessitem percorrer grandes distâncias até o mercado, concentrado em uma área específica, além da publicidade e fácil visualização propiciada pela instalação de pontos comerciais nas vias de maior fluxo de pessoas.

As mudanças não se restringem às ruas, abarcam também os espaços públicos localizados nas suas extremidades. Praças inicialmente de entorno residencial, gradativamente tem a paisagem alterada, as casas são substituídas por comércio e as ruas passam de pacatos espaços de lazer para ambientes impessoais e vazios.

Com essa mudança na conformação da paisagem de praças e vias, altera-se também a forma como essas se relacionam. A rua residencial transmuta-se em zona de comércio, de tráfego intenso de veículos e pessoas, ao mesmo tempo a praça perde o entorno de casas e passa a receber novo público, nem sempre interessado em lazer. O novo contexto da praça modificará sua configuração e a forma como ela passa a ser encarada. $O$ presente trabalho pretende avaliar essa relação da praça com seu novo entorno e como a mudança na configuração da via interfere na paisagem e apreensão desse espaço público.

Foram enfocadas praças de bairros originários de conjuntos habitacionais, localizados na periferia da cidade de Teresina: a praça dos Correios, localizada no Conjunto Habitacional Itararé, a praça da Integração, no Conjunto Habitacional Parque Piauí e a praça e Espaço Cultural Desembargador Vicente Ribeiro, no Parque Promorar.

\section{2 - Descrição dos bairros}

O Conjunto Habitacional Parque Piauí, foi o primeiro conjunto habitacional de Teresina, realizado pela Cohab, em 1968, localizando-se na zona sul da cidade. Por falta de infra-estrutura sua ocupação foi dificultada nos primeiros sete primeiros anos. Atualmente o conjunto tem aproximadamente 13.000 pessoas, com renda média mensal das pessoas responsáveis pelo domicílio de $\mathrm{R} \$ 617,00$ segundo dados de 2000 (TERESINA, 2005).

Com o objetivo de extinguir favelas que haviam se apropriado de terreno público, o Governo Federal cria, em 1982, o programa Promorar, que visava a construção de casas populares pela Cohab, para receber essa população. Dos bairros estudados é o que apresenta a menor renda média mensal do responsável pelo domicílio, correspondendo a $\mathrm{R} \$ 337,99$, segundo dados de 2000 (TERESINA, 2005).

O bairro Itararé, localizado na zona sudeste, ocupa área que pertencia à Fazenda Itararé, que deu nome ao bairro. Sua população gira em torno de 41.000 habitantes e a renda média mensal das pessoas responsáveis pelo domicílio é de $R \$ 406,39$, segundo dados de 2000 (TERESINA, 2005). 
Os conjuntos habitacionais contam com praças, escolas, hospitais, postos policiais e mercados, apresentam infra-estrutura já consolidada, como conseqüência, muitas vilas surgem nas suas proximidades a fim de utilizar a estrutura existente. No caso do Conjunto Habitacional Itararé muitas áreas foram sendo ocupadas nas suas extremidades e, posteriormente, transformadas em novos bairros, mas todos de certa forma ainda dependem do Itararé. Este tomou proporção de cidade devido, em especial, ao seu comércio. Muitas pessoas que moram nas adjacências trabalham no Conjunto Itararé ou utilizam os seus serviços.

Os conjuntos habitacionais Parque Piauí e Promorar também têm um comércio ativo, mas não possuem essa característica tão forte de atração, como o Conjunto Itararé, até porque, logo após a construção dos Conjuntos Parque Piauí e Promorar, a Cohab seguiu com a construção de habitações com a mesma infra-estrutura nas suas proximidades, não havendo espaço para tantas ocupações como ocorreu no Itararé.

Nos três bairros, foi o comércio o responsável por uma melhoria nas condições de vida dos moradores, a criação de pontos comerciais próximos às residências disponibilizava produtos que só podiam ser encontrados no mercado. Quanto menor a distância, maior a facilidade de acesso e menor o tempo gasto, considerando principalmente o fato de que em bairros populares as locomoções ocorrem a pé ou, então, usando-se a bicicleta. As vias arteriais apresentam aspectos propícios à fixação de atividades de prestação de serviços e comércios, pois ligam bairros e o fluxo de veículos costuma ser constante, além de possibilitar uma maior visibilidade de qualquer atividade ali implantada.

Muitas pessoas criaram pontos de comércio e de prestação de serviços em suas residências, principalmente quando localizadas nas principais vias de acesso e tráfego. No início, o ponto de comércio se restringia a um pequeno cômodo, improvisado dentro da casa, mas a partir do sucesso do empreendimento o espaço ia sendo ampliado chegando a ocupar muitas vezes toda a casa. A família, então, passava a morar num segundo ou até terceiro pavimento construído com os recursos advindos do comércio, modificando com isso, também, a configuração da paisagem da via. Observa-se a importância do comércio dentro desses bairros como gerador de renda.

Nos bairros pesquisados os equipamentos de lazer existentes são as praças, ginásios e campos de futebol. No Conjunto Habitacional Parque Piauí foram construídas dez praças, sendo que destas praças dez praças, quatro se localizam em avenidas de grande circulação. Já no caso do Conjunto Habitacional Itararé foram construídas nove praças, sendo que quatro se localizam em vias arteriais e o Conjunto Promorar é o que apresenta a maior proporção de praças localizadas nas vias principais do bairro, com um total de sete praças, cinco estão dispostas em avenidas.

\section{3 - Descrição das praças e seus usos}

Observando-se o caso do Conjunto Habitacional Itararé, a alteração no entorno da praça dos Correios localizada na avenida Principal, José Francisco de Almeida Neto, ocorreu à medida que, se intensificava o comércio na avenida e esse acabava incorporando também as ruas adjacentes à praça. Tal fato ocasionou a substituição de residências por pontos comerciais e prestação de serviços, o que implicou em mudanças não só nas características do entorno, como também, na paisagem e na forma como a praça passa a ser utilizada.

Mas a praça ainda apresenta resquícios de suas primeiras formas de apropriação, por ser um espaço extenso. À medida que, se distancia da avenida José Francisco de Almeida Neto, a

178 paisagem da praça dos Correios modifica-se gradualmente passando de comércio e serviços para, predominantemente, residencial. Mudanças essas que não se restringem ao entorno, mas também a maneira como passa a ser utilizada. Nas proximidades da avenida José Francisco de Almeida Neto, o espaço público encontra-se degradado, utilizado apenas como circulação e 
passagem intensa de pessoas (Figura 1), acarretando a destruição da cobertura vegetal (Figura 2) e apresentando barulho intenso.

Já na outra extremidade da praça, verifica-se a diluição dessa agitação e burburinho, e a presença de forração vegetal do solo, como também a volta de dos usuários, que procuram um espaço contemplativo. Como as ruas localizadas mais distantes da avenida José Francisco de Almeida Neto também têm seu fluxo diminuído drasticamente, há um retorno ao esquema: casa-rua-praça todos se unindo harmoniosamente como espaços de lazer.

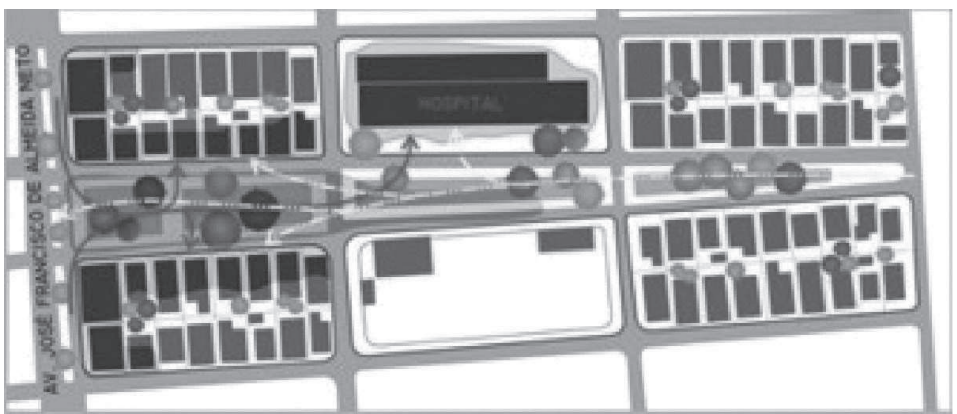

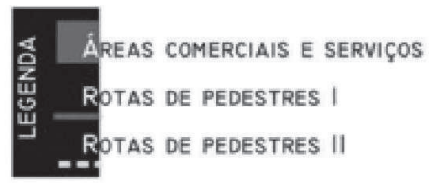

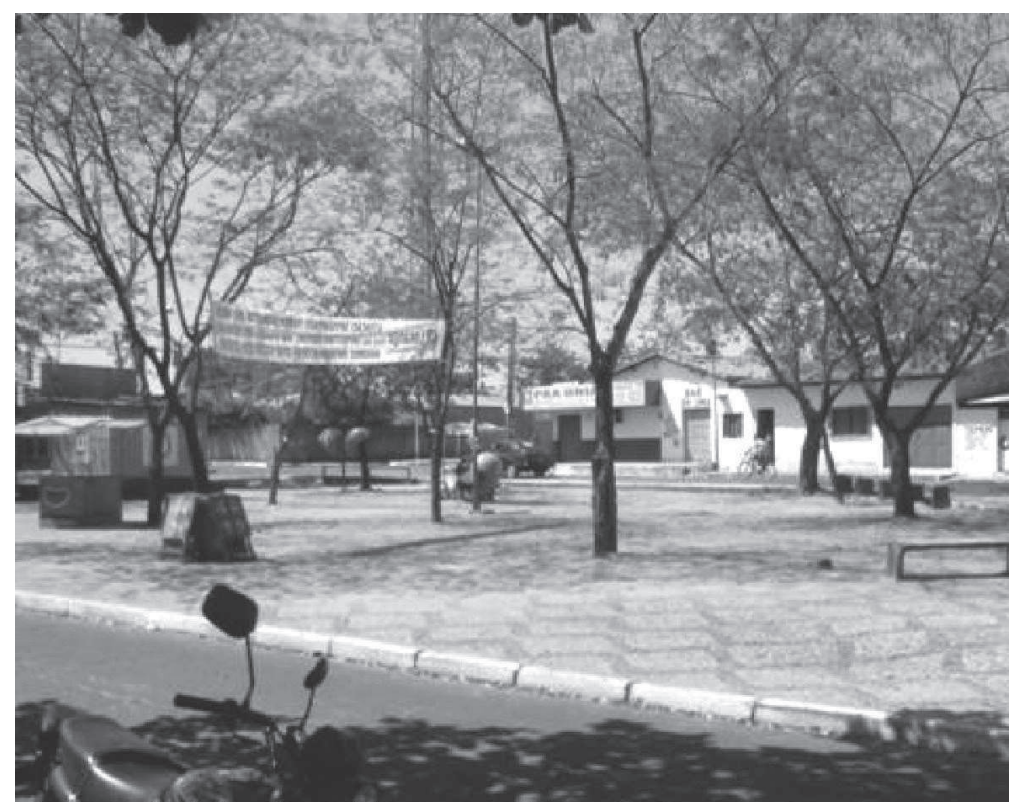

Figura 10: Presença de urubus na praça do Escolão do Mocambinho Fonte: Giuliana Sousa (2005)
Figura 2: Destruição da forração nos canteiros

Fonte: Marta Alves

Nos bairros do Parque Piauí e do Promorar a apropriação das praças pelo comércio ocorre mais lentamente. No Conjunto Habitacional do Parque Piauí, a praça da Integração localizase ao lado da rua Marechal Hermes da Fonseca. Esta rua é caracterizada pelo fluxo intenso de veículos e pessoas, que se dirigem ao mercado ou ao hospital ou ainda, para locais de prestação de serviço de caráter social. Em função deste contexto, as residências estabelecidas nesta rua, gradualmente, se transformam em pontos comerciais e a praça acompanha o processo de mudanças na conformação de sua paisagem (Figura 3). Os espaços pavimentados, localizados próximos à rua Mal. Hermes de Fonseca estão sendo apropriados comercialmente e há uma tendência para o aumento de tais estabelecimentos, em razão da proximidade com o mercado, da facilidade de acesso, tanto de ônibus, carros ou a pé, além da circulação intensa de pessoas (Figura 4). 

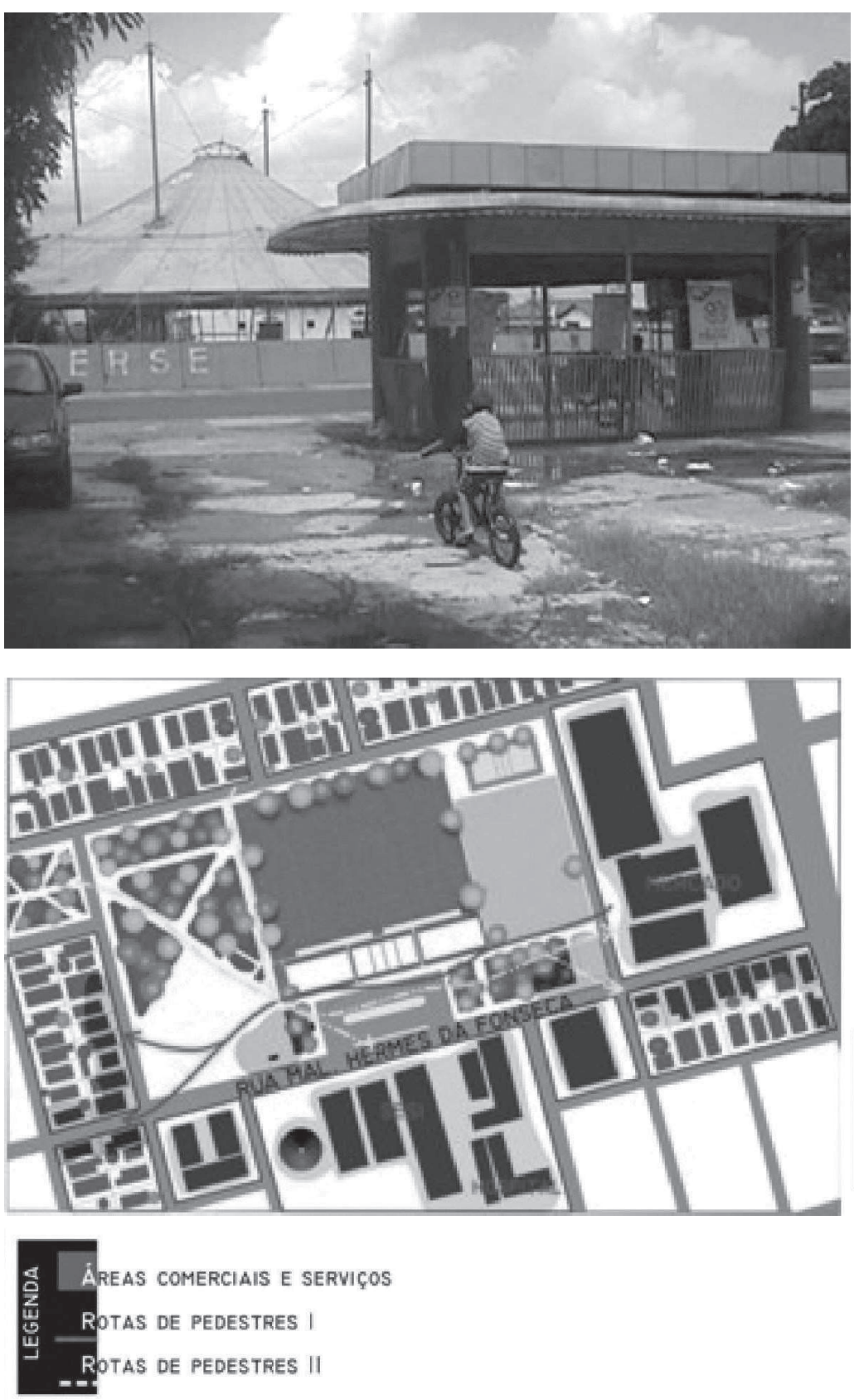

Figura 3. Pontos comerciais, pavimentação destruída, lixo e sujeira, na praça da Integração Fonte: Marta Alves

Figura 4: Planta baixa com mancha de áreas comerciais Fonte: Marta Alves

No outro extremo da praça de entorno predominantemente residencial, o espaço readquire sua função de lazer, os usuários tem uma proximidade maior com a praça e se responsabilizam pela conservação, como se observa nos canteiros preservados (Figura 5). O pequeno fluxo de veículos nas ruas laterais à praça contribui para que esta seja utilizada, pois facilita o acesso, principalmente de crianças e idosos. A rua volta a ser vivenciada como extensão de casa, assim como a praça.

No Conjunto Promorar a praça e Espaço Cultural Desembargador Vicente Ribeiro difere das praças anteriores, pois não apresenta muitos pontos comerciais dentro da sua estrutura. $\bigcirc$ comércio acontece pontualmente e sempre próximo à avenida Deputado Ulisses Guimarães, onde esta em processo de desenvolvimento, existindo ainda muitas casas no seu entorno, ou então, perto da avenida Galícia, onde está localizado o posto de saúde do bairro, principal responsável pela atração de ambulantes (figura 6).

A praça e Espaço Cultural Desembargador Vicente Ribeiro possui seus canteiros preservados próximos à avenida Deputado Ulisses Guimarães (Figura 7). Isso ocorre por não existirem can- 


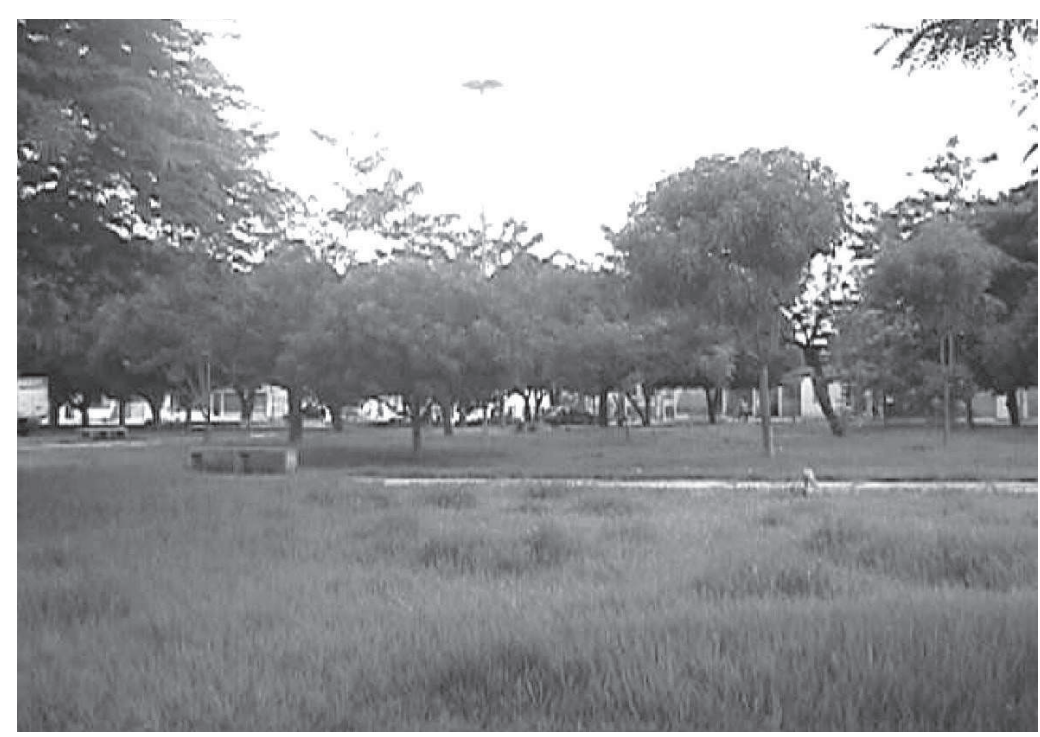

Figura 5: Canteiros

próximos às residências, na

praça da Integração

Fonte: Marta Alves (2006)

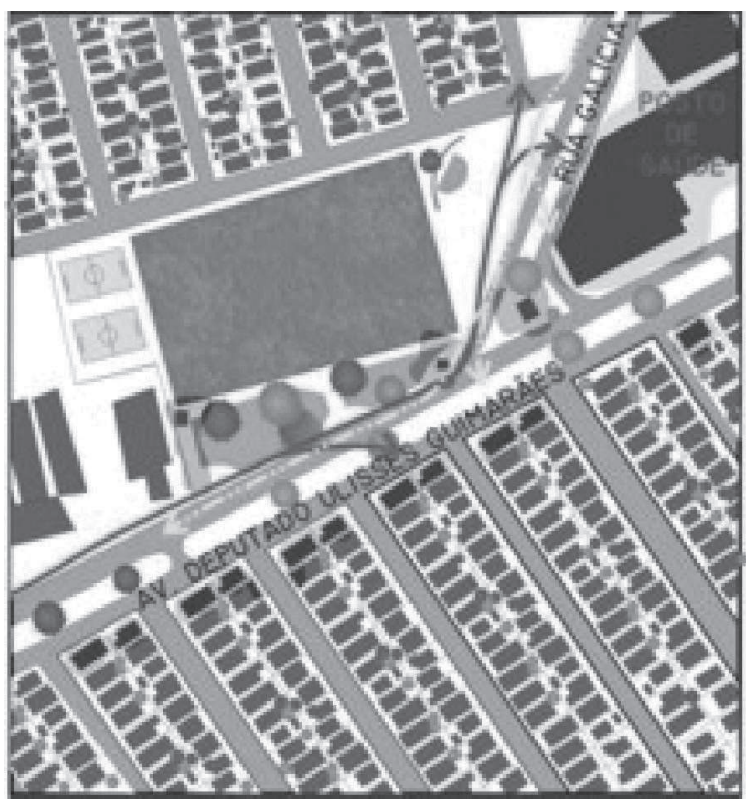

Figura 6: Planta baixa com mancha de áreas comerciais

Fonte: Marta Alves

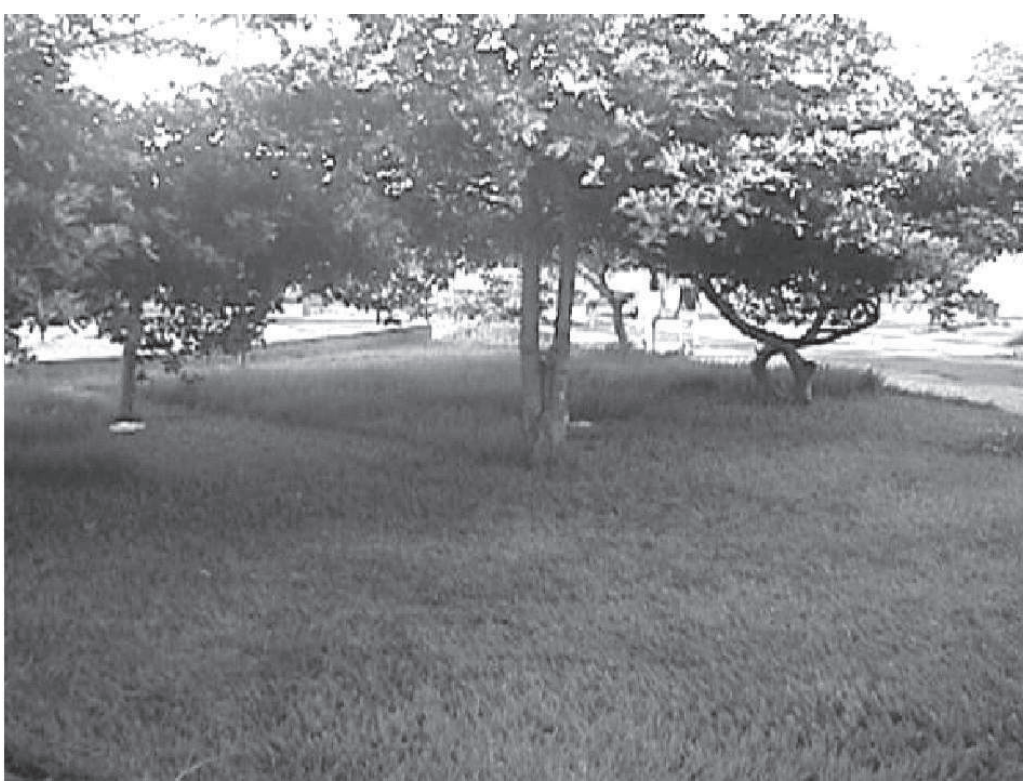

Figura 7: Área verde ao lado da avenida Dep. Ulisses Guimarães, na praça e Espaço Cultural Desembargador Vicente Ribeiro Fonte: Marta Alves (2006) 
teiros perto área onde se concentram as casas e, diferentemente, dos outros bairros estudados, os usuários das praças do conjunto Promorar não se restringem às pessoas que moram nas proximidades, mas toda a comunidade que habita o bairro, que, principalmente, nos fins-desemana se dirigem às praças, independentemente da distância destas para suas casas. $\bigcirc$ que de certa forma ajuda na fiscalização para que não haja apropriação indevida dos poucos espaços de lazer, que essa população tem acesso. Apenas o palco, que é o espaço menos usado, pois, os eventos ocorrem esporadicamente, é o que tem sua estrutura mais desgastada e abandonada (Figura 8).

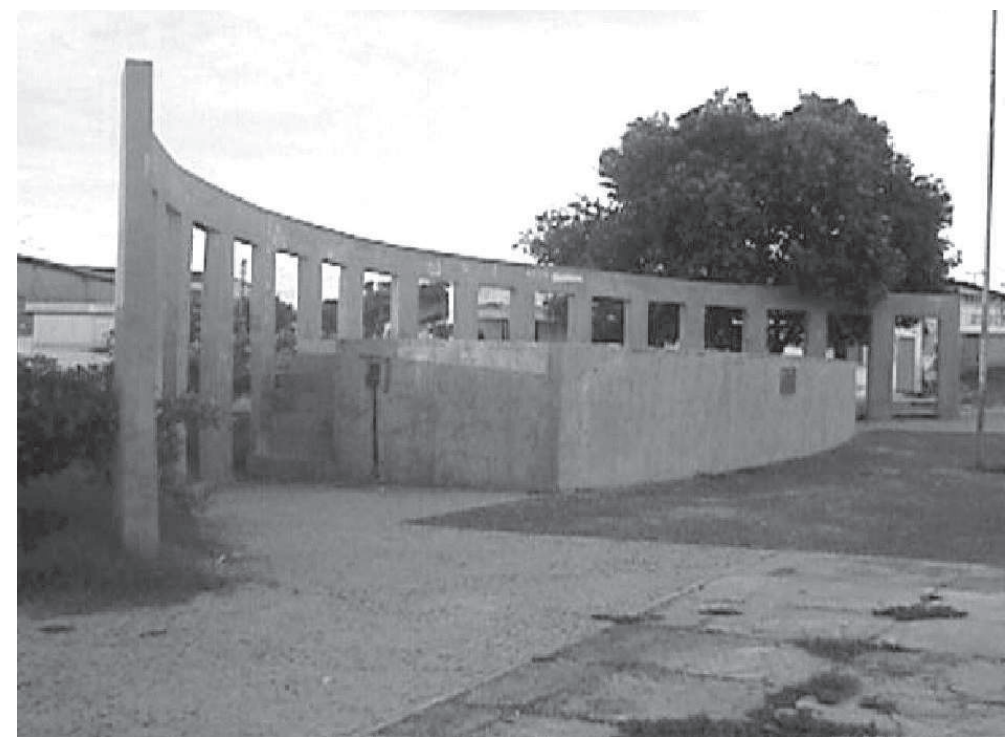

Figura 8: Palco malconservado na praça e Espaço Cultural Desembargador Vicente Ribeiro Fonte: Marta Alves (2006)

Sabe-se que as praças têm mudado de funções, desde sua origem até os dias atuais, acompanhando as transformações da sociedade. Nas praças contemporâneas, segundo Robba e Macedo (2002, p. 152),

"[...] o programa engloba todas as funções do Ecletismo e Modernismo, e ainda retorna - naturalmente guardadas as devidas proporções - alguns usos comuns nos antigos largos coloniais: a utilização comercial e o trânsito de pedestres".

Essas atividades devem ser previstas e reguladas nos projetos atuais, principalmente, a partir de espaços multifuncionais e adaptáveis, que possam apresentar uso flexível. Contudo o que se observa nas praças estudadas é a invasão de atividades de comércio informal, sem uma padronização e controle, como ocorre na Praça da Integração, onde estão localizados vários trailers para a venda de lanches (Figura 9), prejudicando o desenho original do espaço, que não previa esse tipo de uso.

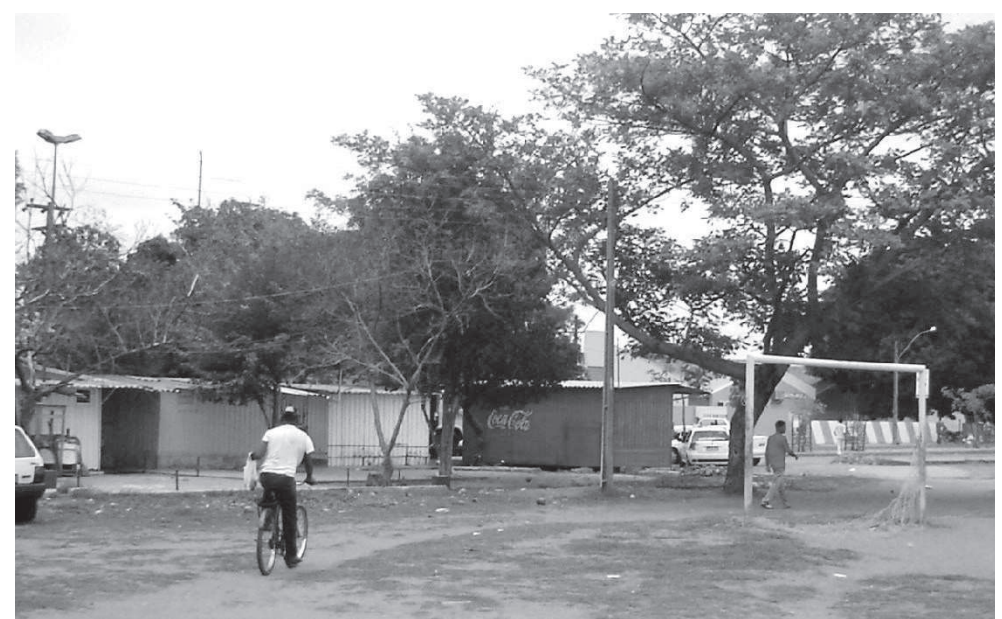

Figura 9: Trailers na praça da Intregação Fonte: Wilza Lopes (2006) 
Faz-se necessário então o acompanhamento desses novos usos dos espaços públicos, para que não venham comprometer a principal característica de praças, definidas em Robba e Macedo (2002, p. 11) como "[...] espaços livres públicos urbanos destinados ao lazer e ao convívio da população, acessíveis aos cidadãos e livres de veículos".

\section{4 - Considerações finais}

Os espaços livres são locais democráticos, onde toda pessoa tem livre acesso, e quando esses locais são apropriados de maneira indevida acarretam problemas a todas as pessoas que os utilizam. O comércio traz consigo o barulho, o qual afugenta as pessoas que procuram tranqüilidade e descanso. Com ele, aumenta, também, o número de pessoas, durante, praticamente todos os dias, que circulando em passeios projetados para uma quantidade menor de usuários, ocasiona a destruição dos canteiros, que passam a ser usados como local de circulação e, conseqüentemente, afugentará aqueles que procuram um local para contemplação.

A expulsão dos usuários durante o dia, também ocorrerá à noite, pois a área ocupada pelo comércio sofre um esvaziamento e criam-se guetos por entre os quiosques, tornando o espaço marginal e inseguro, reforçado, ainda mais, pela falta de residências no entorno.

Se o poder público não fiscaliza essa ocupação, e a população, que é a maior prejudicada, também não o faz, por comodismo ou por necessidade individual de também usá-la comercialmente. As praças perdem o caráter democrático, deixam de ser espaços de todos, pois beneficiam este ou aquele indivíduo em detrimento de toda a população do bairro, visto que não há como favorecer a todos.

\section{Bibliografia}

FARIAS, Ana Maria. Implantação de projetos de espaços públicos no Brasil: Entre práticas técnicas e apropriação popular. In: ENCONTRO NACIONAL DE PAISAGISMO EM ESCOLAS DE ARQUITETURA E URBANISMO NO BRASIL, 5, 2000. Rio de Janeiro. Anais... Rio de Janeiro: FAUUFRJ, 2000. 1 CD-ROM.

HERTZBERGER, Herman. Lições de arquitetura. Rio de Janeiro: Martins Fontes, 1996.

MACEDO, Silvio S. Espaços livres. Paisagem e Ambiente: Ensaios. São Paulo: FAUUSP, n. 7, 1995.

MARX, Murilo. Cidade brasileira. São Paulo: Melhoramentos/Edusp, 1980.

MORRIS, A. E. J. História de la forma urbana - Desde sus orígenes hasta la Revolucion Industrial. 6. ed. Barcelona: Editora GG, 1998.

ROBBA, Fabio; MACEDO, Silvio Soares. Praças brasileiras. São Paulo: Edusp, 2002.

SANTOS, Carlos Nelson F. dos. A cidade como um jogo de cartas. São Paulo: Projeto, 1988.

SEGAWA, Hugo. Ao amor do público: Jardins do Brasil. São Paulo: Studio Nobel, 1996.

TERESINA - Secretaria Municipal de Planejamento - Semplan. Teresina em bairros. Teresina: Prefeitura Municipal de Teresina. [2000?]. Disponível em: <http://www.teresina.pi.gov.br/novothe/pagina_blank.asp?link=http://www.teresina. pi.gov.br/semplan>. Acesso em: 2 dez. 2005.

TRAMONTANO, Marcelo; SANTOS, Denise Mônaco dos. Condomínios fechados: Um olhar arquitetônico. São CarlosSP. Primavera de 2001. Disponível em: <http://eesc.usp.br/nomads/livraria_artigo_online_condominios_olhar.htm> Acesso em: 3 abr. 2004. 